\title{
Challenges and perspectives of Volgograd Region place marketing in light of FIFA World Cup Russia $2018^{\mathrm{TM}}$
}

\author{
Anna Viktorovna Lavrentyeva \\ Volgograd State University \\ Volgograd, Russia \\ lavra.ne@mail.ru,oponir@volsu.ru
}

\author{
Sergey Sergeevich Kuzmin \\ Volgograd State University \\ Volgograd, Russia \\ kuzmin.iure@gmail.com,marketech@volsu.ru
}

\author{
Pavel Valerievich Timachev \\ 2018 FIFA World Cup Russia LOC \\ Volgograd, Russia \\ pavel.timachev@mail.ru
}

\begin{abstract}
The article presents importance of elaborating a host-city long-term development plan is required to reach synergies from the efforts of all concerned and raise solid investments as a result of complex approach to studying impact of large-scale sports events on social and economic development of the region. It describes the institutional uncertainty and socioeconomic risks arising during the preparation period and holding major sporting events.
\end{abstract}

Keywords: place marketing, large-scale international sport events, institutional aspect, infrastructural aspect, social and economic aspects, effective development of the region, program targeted strategy

\section{INTRODUCTION}

One of the major goals of hosting large-scale international sport events is promoting the country image, as well as the regions involved. Social, economic, institutional, infrastructural, and touristic spheres of the region are influenced due to necessity to comply with world-class standards imposed by international institutions. These requirements are applied to such sport events as the Olympic Games, Student Games, World Cups, etc.

Locating large-scale international sport events in global capitals is passing in history. It is determined by sustainability concept and legacy left by the event to the region and the inhabitants. Large-scale international sport events held at high level as per high-quality standards have become so called area brands (for example, Kazan) thus improving quality of living of the local population.

\section{MATERIALS AND METHODS.}

Optimal development strategy of the region hosting largescale sport events and its efficient implementation demands a system embracing of institutional, infrastructural, social and economic, and legal aspects effective development of the region and its infrastructure during preparing, holding, and further using resources such a large-scale event as FIFA World Cup 2018 is finished.

\section{MODERNIZATION AS A FACTOR OF SOCIAL WELL-BEING}

Sports tend to be developing sustainably from social and cultural points of view. However, while organizing a largescale international sport event one should keep in mind possible risks.

According to Brookings Institution, experts esteem that Russia looses 2.25-3.0\% of GDP annually due to improper spatial organization. The losses are caused by destructive independence of economic complexes of certain regions, weakness of interregional relations and inefficient cooperation, high asymmetry between budget revenues of Russian regions and increasing asynchrony of their development, combination of infrastructural development redundancy and shortage in regional profile of macroeconomic space, etc.

Territorial belonging of large-scale international sport events hosted by certain cities or countries is an urgent issue of sports industry. It influences positioning, image making, recognition and maintaining reputation of the territory during large-scale sport events. Such events become brands of the territories; aim at improving reputation of the host country in the eyes of both global and local communities if organized at the highest quality standards.

Sports as a social institution and cultural phenomenon tends to strengthen its role. Successful image of the territory depends on how the image, deliberately formed by a subject, 
of a certain area corresponds to its objective qualities from the one hand and to expectations and demands of the target audience form the other hand. However, efforts aimed at hosting large-scale events come with such threats as capital intensity/ low return of the investments, scarcity of resources and low demand for the venues after the event.

\section{ANALYSIS OF INDEX OF SOCIAL FEELING IN THE REGION AND RUSSIA}

Economic space of Russian regions differs in variety of human, natural, and technological resources and factors, as well as in specific nature of institutional, organizational, and information environments of economic activities that are imposed on by historically developed distinctions in sectoral and territorial structures of economy that do not tend to even. Each of the 85 Russian regions is a unique combination of internal factors of area production performed under a certain combination of natural, economic, and social conditions.

Economic environment for marketing operations as a management system complex has not formed yet in Russia [1]. The following characteristics of marketing in Russia can be observed:

1) increased attention to certain marketing models;

2) practical use of only certain marketing functions;

3) limited access to reliable information required for domestic marketing;

\section{4) underdeveloped infrastructure.}

Place marketing is focused on strengthening the area or region from economic point of view, especially regional economy. Hosting FIFA World Cup Russia 2018 and the related events (preliminary draw, world media agencies tours, etc) provide a unique opportunity for the region to be promoted worldwide.

The major task of the region is to rethink conceptual framework of marketing strategies development and mechanisms of their implementation at the regional level of economy.

Despite undoubted significance of sport events, the hosting part faces a number of challenges. Insufficient funding is one of them. In this case looking for financial support becomes a crucial issue. Major sources of funds for implementing the projects are investors, sponsors, and partners looking for whom is not an easy task and in case of failure, it is the regional budget that bears the burden. Short-term character of large-scale international sport events should be taken into consideration. However, one of key tasks is to keep positive impact of the event on regional economy and image as long as possible [2].

Coordinating actions of the state and private investors within a concerted strategy based sustainable development model is a prerequisite [3]. Principles of public and private partnership must be based on separation between commercial (competitive) element with only entrepreneurs and supporting element aimed at creating favorable conditions supervised by the state either self-acting or in partnership with private companies.

A particular task is to reveal possible ways of further regional development as FIFA World Cup 2018 legacy based on "the best practices" of the host regions and the world experience as well as applying event management fundamentals to development concept of the region [4].

In their work " Mega Sporting Events and Legacy: The Case of the 2014 World Cup" Airton Saboya Valente Junior and Joan Noguera Tur investigate impact of large sports events on economy, social sphere, city and tourism development [5]. While general costs for the 2014 World Cup is 29.6 billion reals Brazilian economy is to get 112.8 billion reals.

The following sectors will gain more profit:

1) construction;

2) production;

3) business services;

4) public utilities;

5) information services;

6) leisure and tourism.

FIFA World Cup legacy can also be described as follows (pic. 1):

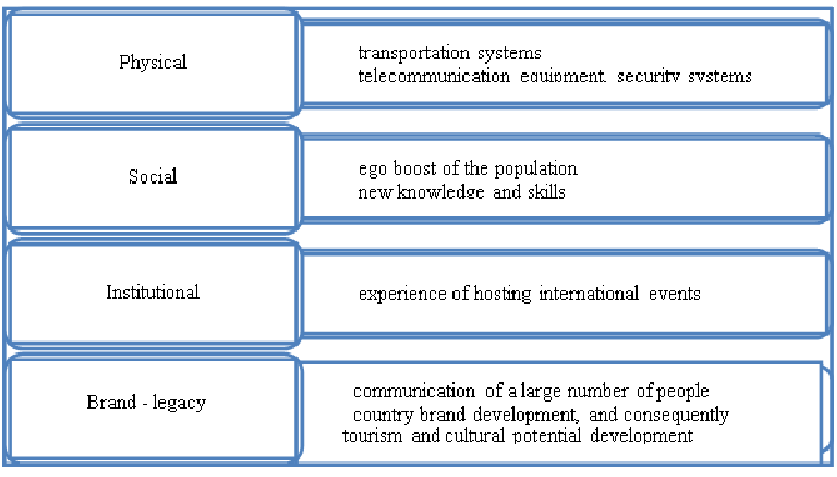

Picture 1 - FWC Legacy

According to different sources provides 643551.6 million rubles, including 92212.2 million rubles from the host-city budgets to be spent on the World Cup 2018 preparation. Also according to Swiss Appraisal specializing in business and investment projects appraisal, Russian expenditures associated with the World Cup 2018 will exceed ten-fold the expected returns from hosting the Cup.

SWOT-analysis was carried out to estimate contemporary place marketing in Volgograd Region (table 1). 
TABLE I.

VOLGOGRAD REGION SWOT-ANALYSIS

\begin{tabular}{|c|c|}
\hline Strengths & Opportunities \\
\hline $\begin{array}{l}\text { Possibility of new market sectors } \\
\text { development; } \\
\text { Interest of potential investors; } \\
\text { Favorable geographic location for } \\
\text { saling goods to Russian regions and } \\
\text { near and far-abroad countries; } \\
\text { Upsurge of business activity (33 } \\
\text { thousands in the end of 2016); } \\
\text { Birthrate increase and death rate } \\
\text { decrease; } \\
\text { Average wage (nominal and real) } \\
\text { increase; } \\
\text { Large educational institutions } \\
\text { (colleges, universities) }\end{array}$ & $\begin{array}{c}\text { Increase of domestic demand; } \\
\text { Strengthening the region in SFD as a } \\
\text { center of manufacturing } \\
\text { entrepreneurship; } \\
\text { Attracting people from other regions; } \\
\text { Increasing volume of domestic } \\
\text { demand; } \\
\text { Reducing rental rate and trade } \\
\text { margin. }\end{array}$ \\
\hline $\begin{array}{c}\text { Weaknesses } \\
\end{array}$ & Threats \\
\hline $\begin{array}{c}\text { Reduction in loan services } \\
\text { availability; } \\
\text { One market segment is more } \\
\text { developed (trading) that causes } \\
\text { disadvantage for other businesses; } \\
\text { Administrative barriers preventing } \\
\text { from entering the market; } \\
\text { Population reduction; } \\
\text { Ageing of population; } \\
\text { Highly qualified personnel outflow } \\
\text { to Russian metropolitan areas and } \\
\text { abroad; } \\
\text { Shortage of labors and engineers; } \\
\text { Low purchasing power of } \\
\text { population. }\end{array}$ & $\begin{array}{c}\text { Capturing the market by large chain } \\
\text { outlets; } \\
\text { Utility rates growth; } \\
\text { Unfair competition; } \\
\text { Market appearance of import } \\
\text { substitute goods from other Russian } \\
\text { regions. } \\
\text { Losing by Volgograd status of a city } \\
\text { with a million-plus population; } \\
\text { Risk of ethnic conflicts. }\end{array}$ \\
\hline
\end{tabular}

The SWOT - analysis made it possible to reveal unique advantages of Volgograd Region:

- developed transportation infrastructure;

- high industrial potential;

- business development support in the whole territory.

- Major problems of Volgograd Region:

- low living standards;

- high human migration;

- insufficient entertainments for tourists;

- low investment climate

- poor promotion of Volgograd Region.

Thus, analysis of strengths and weaknesses of the region demonstrated evaluation of place marketing. The region is characterized by poor developed tourist areas, growing competition with neighbor regions, and low living standards. Volgograd Region ranks in the middle or in the low part showing poor spheres of life.

Unique natural resources, manufacturing local goods, and being one of the key transportation hubs of SFD make Volgograd Region attractive to investors that should also be taken into account.

Innovative methodology based on a combination of institutional, infrastructural, social and economic, industrial, innovative, marketing, resource, and legal analysis is suggested to work out legacy concept of regions hosting largescale international sports events in addition to theory of city competitiveness.

Host-city has to correspond to the latest international standards. First of all, it is accommodation, telecommunications, and transportation infrastructure. All the mentioned global projects are taking place in Volgograd Region:

- construction of the stadium for 45000 seats;

- reconstruction of training sites: "Zenit" stadium, VGAFK, "Olympia" stadium, country club "Olympia";

- building 3-star hotels: "Hampton by Hilton", "ParkInn by Radisson";

- building 4-star hotel: "Hilton Garden Inn";

- reconstruction of airport complex: runaway reconstruction and high speed taxiway construction;

- reconstruction of "Shosse Aviatorov" road from Volgograd International airport to Istoricheskaya Street ("Samarsky Crossing");

- construction of 0 Prodolnaya road (lateral road) with junction of Kalinina street road in Voroshilovsky district and Khimicheskaya street in Central district;

- construction of a railway platform near "Akvarel" trade center;

- reconstruction of Volgograd-1 railway station;

- major repairs of the existing healthcare facilities;

- decorating and landscaping of the Central Embankment named after 62nd Army;

- promotion of Volgograd as a host-city;

- construction and reconstruction of energy complex units.

Successful implementation of the listed above projects during FIFA World Cup Russia 2018 ${ }^{\mathrm{TM}}$ will improve especially transportation infrastructure as transport system has to be modernized regardless hosting the event. Other infrastructural elements such as sports, water supply lines, electric substations, etc. should also be taken into account.

Due to investments into sports sector, Volgograd Region may become one of the leaders in physical training and sports in SFD. Building new facilities can give a boost to small and medium-size entrepreneurship in the region.

More than 13,000 people have been involved into construction of the FIFA World Cup Russia 2018 ${ }^{\mathrm{TM}}$ facilities. More than 100 thousand jobs are going to be created later at the operational stage [6], that in its turn may result in increase in population and cultivation of new territories of Volgograd Region.

Thus, FIFA World Cup Russia $2018^{\mathrm{TM}}$ will leave behind legacy that will become a milestone in place marketing development. Sports and entertaining events cover a large target audience. Such events play an important part in 
development of the region by means of attracting potential consumers, investors, and creating and arranging recreation areas in Volgograd Region.

FIFA World Cup Russia $2018^{\mathrm{TM}}$ is a large investment project that aims at reaching certain goals for developing the territory of the region with the use of tangible, financial, labour, and other resources as well as managerial decisions and activities on their application. FIFA World Cup attracts the largest audience and requires larger media coverage. Once in every four years global attention is attracted to this event for a whole month.

Volgograd Region Administration is going to spend 24254.3 million rubles to prepare for the FIFA World Cup [7]. Apart from the mentioned projects healthcare and energy facilities, utilities, security system and law enforcement bodies are going to be modernized; rolling stock of "Volga Region Railways" (a subsidiary of OJSC "RZhD") will be renewed for the FIFA World Cup Russia $2018^{\mathrm{TM}}$. Large number of personal such as volunteers, stewards, hospitality staff are to be trained to serve flows of guests, tourists, and fans arriving from other regions and countries. To train volunteers for the FIFA World Cup Russia $2018^{\mathrm{TM}}$ Local Organizing Committee "Russia-2018" selected 15 volunteer centers all over Russia. One of them is based on Volgograd State University. The Center is to train 1,300 volunteers. Besides, Regional Volunteer Center was established to train city volunteers whose duties will be to assist in the streets, fan fest ground, public transport stops close to the FIFA World Cup Russia $2018^{\mathrm{TM}}$ sites.

Volgograd and its region will gain considerable perspectives in developing place marketing from the projects including:

1. a unique chance to refresh regional infrastructure, create new jobs, improve quality of living of Volgograd Region and Volgograd inhabitants.

2. transportation infrastructure is being improved. Volgograd is a capital city of Volgograd Region therefore investing into high-quality road carpet and relevant road infrastructure will facilitate economic relations with other Russian regions and foreign countries.

3. increasing tourist attractiveness by means of creating new tourist routs, sites, and training tourist guide-interpreters.

4. building 3, 4, and 5-star hotels according to FIFA requirements will contribute to attracting large international hotel brands to the region.

5. designing city brand. Area branding activities have been accompanying large-scale sport events. Logotype is the main element of brand. It should trigger associations in people's minds with the place of a tournament. Brand is important for a city as for any commercial company. As it links the place with the target audience forming loyalty to the place and its sites at emotional level as well as attracting additional investments that will improve business climate in the region.

Hosting FIFA World Cup Russia 2018 ${ }^{\mathrm{TM}}$ promotes Volgograd Region and speeds up its development. It may also result in increasing extra sources revenues to the regional budget. Volume of foreign investments and employment rate are increasing due to development of construction, hotel, and tourism sectors.

Effective use of sports, tourism, and transportation infrastructures after FIFA World Cup Russia 2018 partnership between the state and business taken as a whole will produce economic and social effect. Implementation of all the projects will lead to growth of social, tourist, and other spheres of life both in Volgograd and in the Region.

Nevertheless, implementation of such a large-scale project brings certain risks determined by tough economic environment and lack of experience in hosting large-scale sports events in Volgograd Region.

Key problem of place marketing is financing the infrastructure as budget funds are not sufficient and regional investment attractiveness is low.

Poor transportation infrastructure is another problem that negatively affects development of Volgograd Region, operation of emergency services, and daily living activities of the locals and guests of the Region. Condition of the roadtransport complex is the "face" of the region for its guests and potential investors.

Volgograd Region Government is preparing a road map with 34 objects for reconstruction that have been included into FIFA World Cup Russia 2018 ${ }^{\mathrm{TM}}$ Preparation Programme. 550 million rubles have been disbursed for this reason. [8]. One of major problems of Volgograd Region is lack of concise and developed investment projects, shortage or total absence of funds for pre-project and project stages, insufficient number of specialists capable of developing projects as required by prospective investors.

The newly built facilities may be left unused after FIFA World Cup Russia 2018 ${ }^{\mathrm{TM}}$. Unless tourism regional infrastructure is well designed, the flow of tourists will decrease sharply. More than three 3-star and more hotels will be on the brink of bankruptcy, the personnel will likely lose jobs. It will result in increase of unemployment rate and working population outflow to other regions.

Hosting FIFA World Cup Russia $2018^{\mathrm{TM}}$ is a large-scale project and its impact on place marketing, social and economic status of the region will become evident only after the World Cup. The region will turn into cultural and tourism, business center with a developed transportation network.

FIFA World Cup Russia 2018 remarkable event for the region, as it will boost development of all spheres of the region. Volgograd has a chance to record itself as a city of high tourist, cultural, sports, and investment opportunities, to become more accessible and competitive.

When the public esteem management of the FIFA World Cup Russia $2018^{\mathrm{TM}}$ as a global event at a high level then Volgograd Region will get a real chance to come open for the rest of the world.

Programme and targeted strategy of territory development falls in the category of solving ambitious and lasting problems 
that fail to be solved in the ordinary course of territory development. It requires taking special measures, good organization, and all possible resources mobilization in the region.

When applying programme and targeted method to place marketing there is need for conferring a higher level of specificity, clearer objective statement that do not possess distinct numeric expressions but are clear enough to understand programme milestones in order to set directions of actions.

By 2018 Volgograd Region will be modernized, transportation infrastructure will be improved that will make both locals and tourists more mobile and allow them travelling safe and comfortable, there will be formed a unified regional space. Possibilities of sports, accommodation, and road infrastructures will be used for attracting tourist and investment flows including bid campaigns aimed at hosting large-scale international events.

To elaborate the programme and targeted strategy three groups of place marketing strategies aimed at attracting tourists, developing industrial complex or regional products exporting are to be distinguished [9]. The strategies can be tentatively named as marketing of image, marketing of infrastructure, and marketing of places of interest. The strategies are detailed in the table below (tab. 2):

TABLE II.

PLACE MARKETING STRATEGIES

\begin{tabular}{|c|c|}
\hline $\begin{array}{c}\text { Marketing } \\
\text { of image }\end{array}$ & $\begin{array}{c}\text { Creating, developing, and promoting positive image of } \\
\text { the place. }\end{array}$ \\
\hline $\begin{array}{c}\text { Marketing of } \\
\text { infrastructure }\end{array}$ & $\begin{array}{c}\text { Constructing comfortable residential, industrial, and } \\
\text { market areas in the territory. Private security and public } \\
\text { order, housing and hotel room stock, road infrastructure } \\
\text { condition, parks and territory improvement, dynamics of } \\
\text { production and market infrastructures, unemployment rate } \\
\text { and investment behavior must be ensured and provided. }\end{array}$ \\
\hline $\begin{array}{c}\text { Marketing of } \\
\text { places of } \\
\text { interest }\end{array}$ & $\begin{array}{c}\text { Promoting wildlife attractions (embankments, parks, } \\
\text { mountains, etc.), historical legacy (museum, samples of } \\
\text { architecture), recreation and cultural facilities (stadiums, } \\
\text { shopping centers). }\end{array}$ \\
\hline
\end{tabular}

Thus, place marketing strategy focuses primarily on modelling, maintaining or changing the consumers' opinion to keep attractiveness, prestige of the territory in whole, quality improvement of daily living and business activities in the territory as well as on increasing appeal of natural, financial, social, labour, and material and technical resources. It also seeks for opportunities to regenerate such resources.

Programme and targeted strategy is based on three place marketing strategies (table 3):

\section{TABLE III. PROGRAMME AND TARGETED STRATEGY} OF VOLGOGRAD REGION PLACE MARKETING

\begin{tabular}{|c|c|}
\hline Marketing of image & Promoting Volgograd as a Host-City \\
\hline \multirow[t]{3}{*}{ Marketing of infrastructure } & Reconstruction of parks \\
\hline & Updating hotels \\
\hline & Creating new jobs \\
\hline \multirow{2}{*}{$\begin{array}{l}\text { Marketing of places of } \\
\text { interest }\end{array}$} & Designing unique tourist routs \\
\hline & $\begin{array}{l}\text { Developing historical and museum } \\
\text { complexes of Volgograd region }\end{array}$ \\
\hline
\end{tabular}

Thus, implementation of the programme and targeted strategy will allow seeing the way of development. Successfully implemented programme will allow attracting tourist flows to the territory, improving people's quality of life, increasing investments and Volgograd Region budget revenues through tax collection. Regional competitiveness also gets stronger.

There going to be four group matches during the FIFA World Cup Russia 2018 ${ }^{\mathrm{TM}}$ in Volgograd. According to the Final Draw results fans and football teams of England, Tunisia, Kingdom of Saudi Arabia, Egypt, Iceland, Nigeria, Poland, and Japan are going to come to Volgograd. Over 2 million tourists are expected to visit Volgograd region in 2018 [8]. To implement place marketing strategy the target, executives, and a list of activities have to be enlisted.

TABLE IV. ALGORITHM OF PROGRAMME TARGETED STRATEGY IMPLEMENTATION

\begin{tabular}{|c|c|}
\hline \multicolumn{2}{|r|}{ Strategy «Marketing of image» } \\
\hline Target & $\begin{array}{l}\text { Volgograd is known as a city of victories. It is true but most } \\
\text { tourists know the city as Stalingrad. Indeed, there is no point in } \\
\text { forgetting the victory but it is not worth promoting Volgograd } \\
\text { as a host city by means of victory. For this reason promotion of } \\
\text { Volgograd aims at attracting investors and tourists. }\end{array}$ \\
\hline Activity & $\begin{array}{l}\text { - A year prior to FIFA World Cup Russia 2018 } \\
\text { - Arranging Fan Fest ground for Confederations Cup 2017; } \\
\text { - Participation of Volgograd volunteers in Confederations } \\
\text { Cup 2017; } \\
\text { - Media coverage of the events associated with FIFA World } \\
\text { Cup and Confederations Cup Russia; } \\
\text { - Dressing of the City for FIFA World Cup Russia 2018 }\end{array}$ \\
\hline Executives & $\begin{array}{l}\text { - Volgograd Regional Organizational Committee for } \\
\text { Preparation for FIFA World Cup Russia 2018 } \\
\text { - Volgograd Regional Volunteer Center; } \\
\text { - FIFA World Cup Russia } 2018^{\mathrm{TM}} \text { Volunteer Center (based at } \\
\text { VolSU) }\end{array}$ \\
\hline \multicolumn{2}{|r|}{ Strategy «Marketing of infrastructure» } \\
\hline Target & $\begin{array}{l}\text { Creating favorable conditions for tourists in the region, } \\
\text { new jobs for locals, decreasing outflow of population. } \\
\text { Volgograd id famous for its Cossack traditions and unusual } \\
\text { landscape. }\end{array}$ \\
\hline Activity & $\begin{array}{l}\text { - Reconstruction of Central Park. } \\
\text { - Erecting observation wheel; } \\
\text { - Building up ethnic Cossack village; } \\
\text { - Developing sports area; } \\
\text { - Reconstruction of hotels: } \\
\text {-“Tourist" Hotel (Central District); } \\
\text {-“Akhtuba" Hotel (Volzhskiy); } \\
\text { - Employing locals for FIFA World Cup facilities. }\end{array}$ \\
\hline Executives & $\begin{array}{l}\text { - Volgograd Regional Organizational Committee for } \\
\text { Preparation for FIFA World Cup Russia 2018 } \\
\text { - Volgograd Region Committee on Construction; } \\
\text { - Volgograd Region Committee on work and employment }\end{array}$ \\
\hline \multicolumn{2}{|r|}{ Strategy «Marketing of places of interest» } \\
\hline Target & $\begin{array}{l}\text { Developing and maintaining cultural and historic perspectives } \\
\text { of the region, creating a unique selling point, complex dressing } \\
\text { of territories as consequence of raise in attractiveness. }\end{array}$ \\
\hline Activity & $\begin{array}{l}\text { - Designing unique touristic routs } \\
\text { - Developing historical and cultural complexes. }\end{array}$ \\
\hline Executives & $\begin{array}{l}\text { - Department of culture and tourism of Volgograd Region } \\
\text { - Tourism Development Agency. }\end{array}$ \\
\hline
\end{tabular}

Evaluating the strategy implementation will be possible after FIFA World Cup Russia 2018 ${ }^{\mathrm{TM}}$. 
It should be taken into consideration that indicators to evaluate effectiveness of place marketing strategies implementation have not been elaborated yet.

Most often executive regional authorities evaluate effectiveness as a sum of expired costs, raised funds, participating or setting up exhibitions, festivals, etc. It is certainly hard to measure the expected effect either spontaneous investments or other factors. Time aspect makes it complex as the expected results may become visible only in a certain period.

We believe that effectiveness evaluation of place marketing strategy delivering should base on proxy indicators that allow approximate evaluating result of the delivery from social and economic development of the territory. In our opinion, the system should comprise three indicators: social and economic, regional rankings, polling target groups (locals, tourists, investors).

The following statistical key figures prove effective place marketing: (GRP);

- volume and behavior of gross regional product

- level and dynamics of average income per capita;

- dynamics of raised investments both domestic and foreign;

- increase in the number of tourists into the region;

- dynamics of tax revenues from business;

- inflow/ outflow of the population and youth.

- Below are the most informative ratings of Russian regions:

- national rating of investment climate in Russian regions;

- rating of social well-being of Russian regions;

- family living standards rating of regions.

\section{CONCLUSION}

The statistical figures and ratings above should be taken in entire, complex, and system consideration to analyze effectiveness of Volgograd Region place marketing strategy implementation. To estimate effectiveness at different stages of implementation, to make adjustments and alterations to the place marketing strategy is possible only in case of assuring system approach.
Thus, due to regular monitoring the region can strengthen its positions against neighbor territories, improve its image, increase investments, become more competitive, and stabilize social and economic development of Volgograd Region.

Elaborating a host-city long-term development plan is required to reach synergies from the efforts of all concerned and raise solid investments as a result of complex approach to studying impact of large-scale sports events on social and economic development of the region. It will provide the investors with a distinct picture of the future: what the local market will look like in many years and how the invested money will work after the competitions finish. Hereby, uncertainty and related to it risks decrease; the entrepreneurs can confidently predict investment yields that increases project attractiveness to the investors

\section{REFERENCES}

[1] E.P. Golubkov Marketing research: theory, practice, methodology. - M.: Finpress, 2004.

[2] Robert Baumann, Victor A. Matheson. Infrastructure Investments and MegaSports Events: Comparing the Experience of Developing and Industrialized Countries. URL: http://college.holycross.edu/RePEc/hcx/ BaumannMatheson_MegaEventsDeveloping.pdf

[3] D.P.Frolov, A.V.Lavrentyeva. Institutional pathologies in the economy (marketing of territories, social responsibility of business, bankruptcy, mortgage) // Modern economics: problems and solutions. - 2012. - № 7 . -pp. 35-45.

[4] E.V. Verlup The use of benchmarking tools in the development strategies of the regions // The works of the Free Economic Society. Vol. 189. - M.- 2014. pp. 72-77

[5] Airton Saboya Valente Junior, Joan Noguera Tur. Mega Sporting Events and Legacy: The Case of the 2014 World Cup. -URL: http://www.regionalstudies.org/uploads/Airton_Saboya_Valente_Junior. pdf

[6] Russia 2018 Bid Book URL: http://donland.ru/Data/Sites/1/ media/file/2012/2012_03_treb_stad.pdf.

[7] FIFA official website URL: http://resources.fifa.com/mm/document/ tournament/competition/02/86/77/63/impactandlegacyof2018fifaworldc up_ru_russian.pdf.

[8] Official website of the Committee on preparation and holding of the FIFA World Cup Russia $2018^{\mathrm{TM}}$ matches in Volgograd Region/ URL: http://komitet2018.volganet.ru/upload/iblock/6e9/docum.pdf.

[9] D.P. Frolov. Marketing paradigm of regional development: 2nd edition, add.// Volgograd: VolSU Publishing house, 2013. pp. 157. 